This item was submitted to Loughborough's Research Repository by the author.

Items in Figshare are protected by copyright, with all rights reserved, unless otherwise indicated.

\title{
Versatile routes to selenoether functionalised tertiary phosphines
}

PLEASE CITE THE PUBLISHED VERSION

http://dx.doi.org/10.1039/c0dt00004c

\section{PUBLISHER}

(c) The Royal Society of Chemistry

\section{VERSION}

AM (Accepted Manuscript)

\section{PUBLISHER STATEMENT}

This work is made available according to the conditions of the Creative Commons Attribution-NonCommercialNoDerivatives 4.0 International (CC BY-NC-ND 4.0) licence. Full details of this licence are available at: https://creativecommons.org/licenses/by-nc-nd/4.0/

\section{LICENCE}

CC BY-NC-ND 4.0

\section{REPOSITORY RECORD}

Cunningham, Tom J., Mark R.J. Elsegood, Paul F. Kelly, Martin B. Smith, and Paul M. Staniland. 2019. "Versatile Routes to Selenoether Functionalised Tertiary Phosphines". figshare.

https://hdl.handle.net/2134/15952. 


\title{
Versatile Routes to Selenoether Functionalised Tertiary Phosphines
}

\author{
Tom J. Cunningham, Mark R. J. Elsegood, Paul F. Kelly, Martin B. Smith* ${ }^{a}$ and Paul M. Staniland
}

Received (in XXX, XXX) 1st January 2007, Accepted 1st January 2007

First published on the web 1st January 2007

DOI: $10.1039 / b 000000 x$

\begin{abstract}
${ }_{5}$ New selenoether functionalised tertiary phosphines, based on aryl (2a, 2b) or alkyl (4) backbones, have been synthesised and characterised. $P, S e$-chelation has been achieved upon complexation to square-planar $\mathbf{P t}^{\mathrm{II}}$ (3a) or $\mathbf{P d}^{\mathrm{II}}$ (3b) metal centres. For $3 a$ and $3 b$, weak non covalent $M \cdots$ Se contacts 10 were established using single crystal X-ray crystallography.
\end{abstract}

Tertiary phosphines continue to remain an integral tool in the design and synthesis of new metal based complexes. Hybrid tertiary phosphines, bearing additional donor atoms such as 15 oxygen, have frequently been described as hemilabile by virtue of the soft/hard donor atom combination. ${ }^{1}$ Considerable recent interest has focused on mixed P,O- and P,S-ligands for their fascinating coordination chemistry, ${ }^{2}$ including water-soluble macrocyclic complexes using a weak-link approach, ${ }^{3}$ and 20 catalytic applications. ${ }^{4}$ Tertiary phosphines with an additional selenium donor centre have been very poorly developed in comparison to their lighter Group 16 counterparts. ${ }^{5}$ In contrast, numerous tertiary phosphine selenides $\left(\mathrm{R}_{3} \mathrm{P}=\mathrm{Se}\right)$ have been documented $^{6}$ and there has been much recent interest in 25 phosphorus-selenium chemistry e.g. Woollins' reagent. ${ }^{7}$

$\mathrm{We}^{8}$, and others ${ }^{9}$ have been interested in exploiting the favourable stereoelectronic, solubility and crystalline properties of the 6-phospha-2,4,8-trioxa-1,3,5,7-tetramethyladamantyl cage group in the synthesis of new phosphine ligands. Herein we 30 describe the synthesis of a new, air-stable, selenoether phosphine containing this diamondoid group, along with two further selenoether phosphines and their square-planar dichloropalladium and platinum(II) complexes.

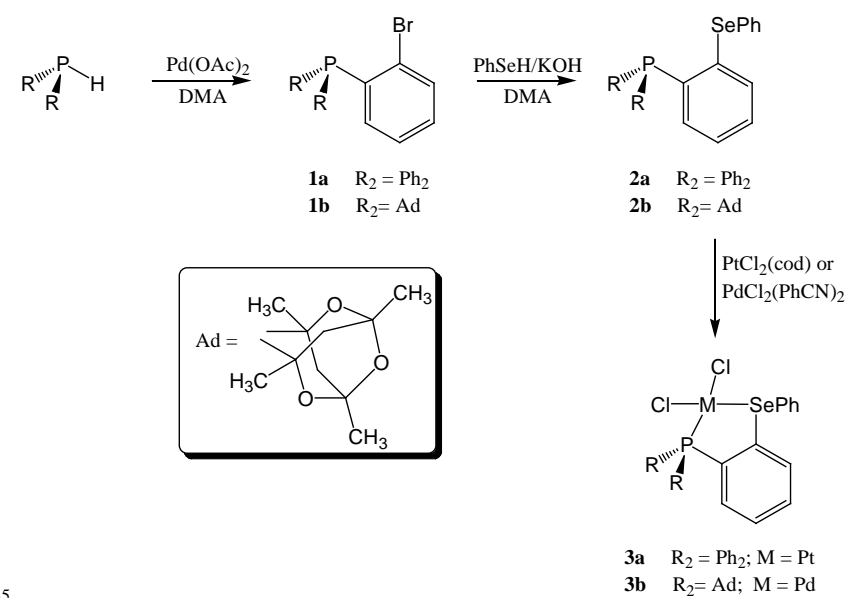

35

Scheme 1

${ }^{a}$ Department of Chemistry, Loughborough University, Loughborough, UK LE11 3TU. Fax: +44 1509 223925; Tel: +44 1509 222553; E-mail: m.b.smith@lboro.ac.uk

$40 \dagger$ Electronic Supplementary Information (ESI) available: [Experimental procedures, spectroscopic data and additional X-ray figures]. See DOI: 10.1039/b000000x/
The synthetic procedure to the new selenoether modified phosphines 2a and $\mathbf{2 b}$ was achieved using standard methodology 45 (Scheme 1). Following a known procedure for accessing bromophosphine $\mathbf{1 a},{ }^{10}$ reaction of the parent cage phosphine, $\mathrm{AdPH}$, with 1-bromo-2-iodobenzene in dimethylacetamide (DMA) under standard $\mathrm{P}-\mathrm{C}$ coupling conditions afforded $\mathbf{1 b}$ in good yield (55\%) as an air-stable crystalline solid. ${ }^{\dagger}$ One 50 noticeable difference in the preparation of $\mathbf{1 b}$, opposed to $\mathbf{1 a}$, was the considerably shorter reaction time to proceed to completion (typically $2 \mathrm{~d}$ for $\mathbf{1 b} ; 5 \mathrm{~d}$ for $\mathbf{1 a}$ ). In the ${ }^{31} \mathrm{P}\left\{{ }^{1} \mathrm{H}\right\}$ NMR spectrum of $\mathbf{1 b}$ a single phosphorus resonance was observed at $\delta(\mathrm{P})-29.6$ $\mathrm{ppm}$, some $25 \mathrm{ppm}$ upfield with respect to 1a [ $\delta(\mathrm{P})-4.9 \mathrm{ppm}]$. ${ }_{55}$ Reaction of either 1a or $\mathbf{1 b}$ with $\mathrm{PhSeH}$ and $\mathrm{KOH}$, in DMA, for 5 $\mathrm{d}$ at $c a .160{ }^{\circ} \mathrm{C}$ afforded $\mathbf{2 a}$ or $\mathbf{2 b}$ in reasonable yields (53\% and $40 \%$ respectively). ${ }^{31} \mathrm{P}\left\{{ }^{1} \mathrm{H}\right\}$ NMR spectroscopy of $\mathbf{2 a}$ and $\mathbf{2 b}$ showed single phosphorus resonances at $\delta(\mathrm{P})-10.0\left[{ }^{3} J(\mathrm{PSe}) 139\right.$ $\mathrm{Hz}]$ and $\delta(\mathrm{P})-34.6 \mathrm{ppm}\left[{ }^{3} J(\mathrm{PSe}) 201 \mathrm{~Hz}\right]$ respectively.

60 Crystals of $\mathbf{2 b}$, suitable for $\mathrm{X}$-ray crystallography, were grown by vapour diffusion of $\mathrm{Et}_{2} \mathrm{O}$ into a $\mathrm{CDCl}_{3}$ solution. ${ }^{\ddagger}$ The molecular structure (Fig. 1) of $\mathbf{2} \mathbf{b}$ revealed crystallisation of a single enantiomer and confirmed the ortho arrangement of the bulky chiral phosphaadamantyl cage and selenoether group. ${ }_{65}$ Metric parameters are broadly as anticipated and the transannular $\mathrm{P}(1) \cdots \mathrm{Se}(1)$ separation $[3.230 \AA]$ suggests cis-co-ordination to metal centres should be feasible. To the best of our knowledge we believe this structure determination represents the first example of a functionalised selenoether tertiary phosphine. 70

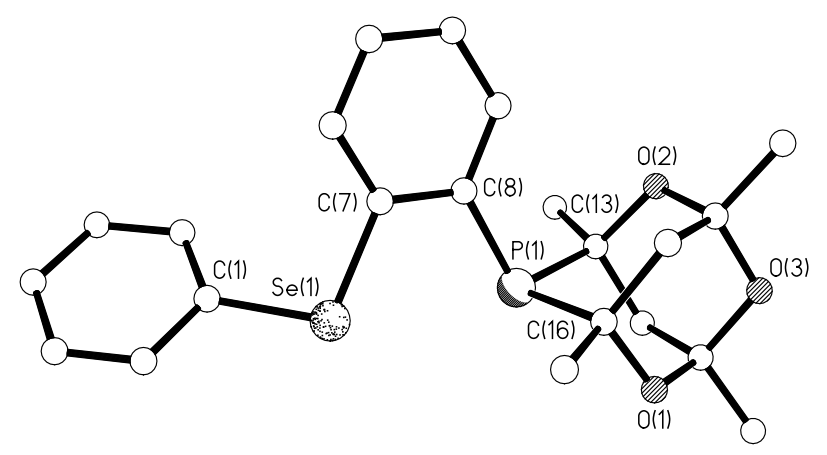

Fig. 1 Molecular structure of $\mathbf{2 b}$. All C-H hydrogen atoms are omitted for clarity. Selected bond distances $(\AA)$ and angles (deg): ${ }_{75} \mathrm{C}(1)-\mathrm{Se}(1)$ 1.919(3), Se(1)-C(7) 1.925(3), C(8)-P(1) 1.844(3); $\mathrm{C}(1)-\mathrm{Se}(1)-\mathrm{C}(7) \quad 102.41(14), \quad \mathrm{Se}(1)-\mathrm{C}(7)-\mathrm{C}(8) \quad 119.7(2)$, C(13)-P(1)-C(16) 92.40(14).

To demonstrate the co-ordination potential of $\mathbf{2 a}$ and $\mathbf{2} \mathbf{b}$, 80 reaction of 1 equiv. of each ligand with either $\mathrm{PtCl}_{2}$ (cod) (cod = cycloocta-1,5-diene) or $\mathrm{PdCl}_{2}(\mathrm{PhCN})_{2}$ in $\mathrm{CH}_{2} \mathrm{Cl}_{2}$ at ambient temperature afforded the dichlorometal(II) complexes $\mathbf{3 a}$ and $\mathbf{3 b}$ in good yields. Crystals of $\mathbf{3 a}$ and $\mathbf{3} \mathbf{b}$ were grown by vapour 
diffusion of diethyl ether into either a $\mathrm{CDCl}_{3} /\left(\mathrm{CH}_{3}\right)_{2} \mathrm{SO}$ or $\mathrm{CH}_{2} \mathrm{Cl}_{2}$ solution (Fig. 2). ${ }^{\ddagger}$ In both cases, P,Se-chelation is clearly evident with $\mathrm{P}(1)-\mathrm{M}(1)-\mathrm{Se}(1)$ bond angles of $90.28(3)$ and $87.902(12)^{\circ}$. Furthermore the M(1)-Se(1) bond lengths [Pt(1)-Se(1) 2.3561(5) 5 for 2a; $\operatorname{Pd}(1)-\operatorname{Se}(1)$ 2.3656(2) for 2b] are consistent with selenoether coordination. ${ }^{11}$ The $\mathrm{M}(1)-\mathrm{Se}(1)-\mathrm{C}(7)-\mathrm{C}(8)-\mathrm{P}(1)$ five-membered rings are essentially coplanar to within $\pm 0.046 \AA$ (for 3a) and $\pm 0.104 \AA$ (for 3b). The interplanar angles for 3a and $\mathbf{3 b}$, as defined by the $\mathrm{Se}(1) / \mathrm{C}(7) / \mathrm{C}(8) / \mathrm{P}(1)$ vs. $\mathrm{Se}(1) / \mathrm{M}(1) / \mathrm{P}(1)$ 10 planes, are $4.9^{\circ}$ and $11.4^{\circ}$ respectively indicating marginal folding along the $\mathrm{P}(1) \cdots \mathrm{Se}(1)$ vector. In addition, there is a clear change in dihedral angle between the phenyl/phenylene rings attached to $\mathrm{Se}(1)$ as a function of chelation. In the free ligand $\mathbf{2 a}$, the dihedral angle is $54.1^{\circ}$ which expands to $87.0^{\circ}$ (for $\mathbf{3 a}$ ) and $82.1^{\circ}$ (for $\mathbf{3 b}$ ). 15 As a consequence, weak non covalent $\mathrm{M}(1) \cdots \operatorname{Se}(1)$ intermolecular contacts $[\operatorname{Pt}(1) \cdots \operatorname{Se}(1) \quad 3.709 \AA$ for $3 a$; $\operatorname{Pd}(1) \cdots \operatorname{Se}(1) 3.787 \AA$ for $3 \mathbf{b}]$ link adjacent molecules into dimer pairs. ${ }^{12}$ Although not shown in Fig. 2, additional $\mathrm{Se}(1) \cdots \mathrm{Cl}(1 \mathrm{~A})$ interactions are present (3.445 $\AA$ for 3a; $3.679 \AA$ for $3 \mathbf{b})$. In the 20 case of 3a this distance is significantly less than the sum of the van der Waals radii for Se and $\mathrm{Cl}$ atoms (3.65 $\AA$ ). ${ }^{13}$

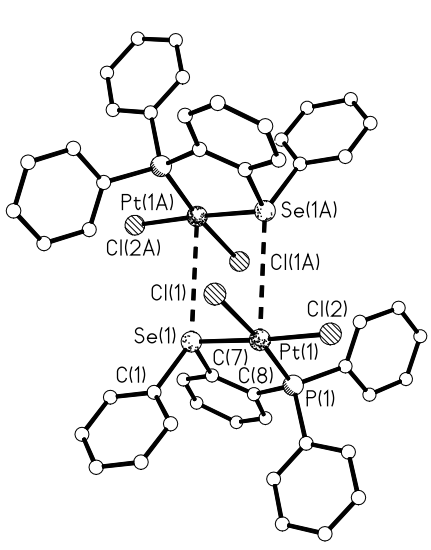

(a)

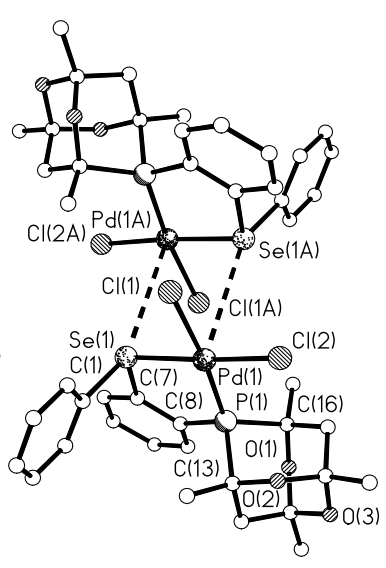

(b)
${ }_{25}$ Fig. 2 Molecular structures of (a) 3a and (b) 3b. All C-H hydrogen atoms are omitted for clarity. For complex $\mathbf{3 b}$ the $\mathrm{CH}_{2} \mathrm{Cl}_{2}$ solvate has been removed. Selected bond distances $(\AA)$ and angles (deg) for 3a Pt(1)-P(1) 2.2094(11), Pt(1)-Se(1) 2.3561(5), $\quad \mathrm{Pt}(1)-\mathrm{Cl}(1) \quad 2.3668(11), \quad \mathrm{Pt}(1)-\mathrm{Cl}(2) \quad 2.3142(11)$; ${ }_{30} \mathrm{P}(1)-\mathrm{Pt}(1)-\mathrm{Se}(1) \quad 90.28(3), \quad \mathrm{P}(1)-\mathrm{Pt}(1)-\mathrm{Cl}(2) \quad 91.89(4)$, Se(1)-Pt(1)-Cl(1) 85.94(3), Cl(1)-Pt(1)-Cl(2) 92.04(4). For 3b: Pd(1)-P(1) 2.2615(4), Pd(1)-Se(1) 2.3656(2), $\quad \mathrm{Pd}(1)-\mathrm{Cl}(1)$ 2.3506(4), $\mathrm{Pd}(1)-\mathrm{Cl}(2)$ 2.3180(5); $\mathrm{P}(1)-\mathrm{Pd}(1)-\mathrm{Se}(1)$ 87.902(12), $\mathrm{P}(1)-\mathrm{Pd}(1)-\mathrm{Cl}(2) \quad 98.800(17), \quad \mathrm{Se}(1)-\mathrm{Pd}(1)-\mathrm{Cl}(1) \quad 84.577(14)$, ${ }_{35} \mathrm{Cl}(1)-\mathrm{Pd}(1)-\mathrm{Cl}(2)$ 88.709(18).

Having successfully demonstrated the preparation of aryl based selenoether phosphines, we also found the ease by which an alkyl backboned selenoether phosphine can be readily 40 obtained. Using an AIBN radical initiated hydroselenation, ${ }^{14}$ reaction of $\mathrm{Ph}_{2} \mathrm{PCH}=\mathrm{CH}_{2}$ with $\mathrm{PhSeH}$ afforded solid 4 (Scheme 2) regioselectively which has been characterised $[\delta(\mathrm{P})-15.4]{ }^{15}$ Reaction of the anti-Markovnikov product 4 with $\mathrm{PdCl}_{2}$ (cod) gave the five-membered chelate complex $\mathbf{5}$ displaying the 45 expected spectroscopic and analytical properties. The significant downfield shift in the ${ }^{31} \mathrm{P}\left\{{ }^{1} \mathrm{H}\right\}$ NMR spectrum of $5[\delta(\mathrm{P}) 62.3$ ppm] is fully consistent with coordination of both $\mathrm{P}$ and Se donor atoms to a single $\mathrm{Pd}(\mathrm{II})$ metal centre.

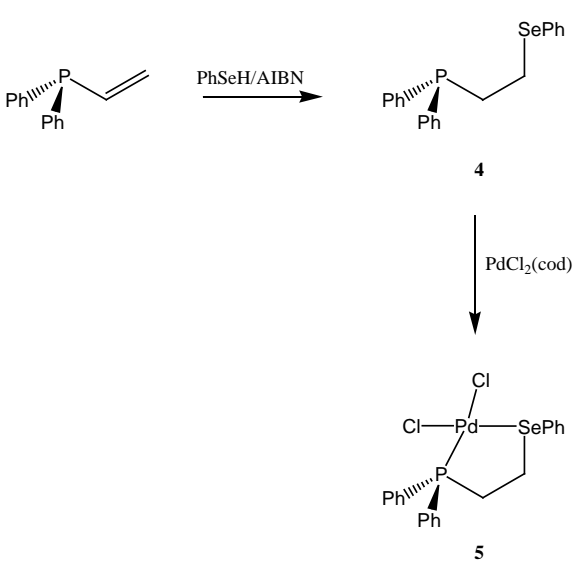

Scheme 2

In summary, we have shown how established synthetic routes can be used to access, hitherto unknown, selenoether modified 55 tertiary phosphines and demonstrated their ease of P,Se-chelation at soft metal centres. Further coordination studies are in progress and results from these will be reported in due course.

\section{Acknowledgements}

60 We would like to thank the EPSRC and Loughborough University for funding (PMS). Johnson Matthey are gratefully acknowledged for the generous loan of precious metal salts.

\section{Notes and References}

${ }_{65} \dagger$ See ESI for synthetic details and characterising data for all new compounds.

$\ddagger$ Crystal data: For $\mathbf{2 b}, \mathrm{C}_{22} \mathrm{H}_{25} \mathrm{O}_{3} \mathrm{PSe}: M_{\mathrm{r}}=447.35$, orthorhombic, space group $P 2{ }_{1} 2{ }_{1} 2_{1}, a=8.1752(5) \AA, b=10.1189(6) \AA, c=$ 24.5004(14) $\AA, V=2026.8(2) \AA^{3}, T=150(2) \mathrm{K}, Z=4, \mu\left(\mathrm{Mo}_{\alpha}\right)$ $7_{0}=0.71073 \AA$, 17792 data measured, 4890 unique $\left(R_{\text {int }}=0.0366\right)$, $d_{\text {calc }}=1.466 \mathrm{~g} \mathrm{~cm}^{-3}, R 1=0.0391$ (for 4049 data with $I>2 \sigma(I)$ ), $w R 2=0.0858$ (all data), and 248 parameters. CCDC xxxxxx. For 3a, $\mathrm{C}_{24} \mathrm{H}_{19} \mathrm{Cl}_{2} \mathrm{PPtSe}: M_{r}=683.31$, monoclinic, space group $P 2_{1} / n$, $a=11.2539(7) \AA, b=13.4809(8) \AA, c=14.7665(9) \AA, \beta=$ $75101.0079(10)^{\circ}, V=2199.0(2) \AA^{3}, T=150(2) \mathrm{K}, Z=4, \mu\left(\mathrm{Mo}^{\circ} \mathrm{K}_{\alpha}\right)$ $=0.71073 \AA$, 19234 data measured, 5350 unique $\left(R_{\text {int }}=0.0357\right)$, $d_{\text {calc }}=2.064 \mathrm{~g} \mathrm{~cm}^{-3}, R 1=0.0276$ (for 4130 data with $I>2 \sigma(I)$ ), $w R 2=0.0557$ (all data), and 262 parameters. CCDC xxxxxx. For 3b, $\mathrm{C}_{22} \mathrm{H}_{25} \mathrm{Cl}_{2} \mathrm{O}_{3} \mathrm{PPdSe} \cdot \mathrm{CH}_{2} \mathrm{Cl}_{2}: M_{r}=709.58$, triclinic, space 80 group $P \overline{1}, a=11.0639(5) \AA, b=11.0640(5) \AA, c=11.7858(5)$ $\AA, \alpha=89.7421(7)^{\circ}, \beta=76.3793(7)^{\circ}, \quad \gamma=68.4046(6)^{\circ}, \quad V=$ 1298.32(10) $\AA^{3}, T=150(2) \mathrm{K}, Z=2, \mu\left(\mathrm{Mo}-\mathrm{K}_{\alpha}\right)=0.71073 \AA$, 11577 data measured, 6012 unique $\left(R_{\text {int }}=0.0110\right), d_{\text {calc }}=1.815 \mathrm{~g}$ $\mathrm{cm}^{-3}, R 1=0.0188$ (for 5490 data with $I>2 \sigma(I)$ ), $w R 2=0.0464$ 85 (all data), and 302 parameters. CCDC $\operatorname{xxxxxx.~All~three~}$ structures were determined routinely.

1 N. C. Gianneschi, M. S. Masar III and C. A. Mirkin, Acc. Chem. Res., 2005, 38, 825.

902 (a) P. A. Ulmann, C. A. Mirkin, A. G. DiPasquale, L. M. LiableSands and A. L. Rheingold, Organometallics, 2009, 28, 1068; (b) C. G. Oliveri, P. A. Ulmann, M. J. Wiester and C. A. Mirkin, Acc. Chem. Res., 2008, 41, 1618; (c) C. G. Oliveri, S. T. Nguyen and C. A. Mirkin, Inorg. Chem., 2008, 47, 2755; (d) A.-M. Valean, S. Gómez95 Ruiz, P. Lönnecke, I. Silaghi-Dumitrescu, L. Silaghi-Dumitrescu and 
E. Hey-Hawkins, New J. Chem., 2009, 33, 1771; (e) T.-W. Chiou and W.-F. Liaw, Inorg. Chem., 2008, 47, 7908.

3 M. J. Wiester and C. A. Mirkin, Inorg. Chem., 2009, 48, 8054.

4 (a) L. Diab, M. Gouygou, E. Manoury, P. Kalck and M. Urrutigoïty,

$5 \quad$ Tetrahedron Lett., 2008, 49, 5186; (b) A. Dervisi, D. Koursarou, L.-l. Ooi, P. N. Horton and M. B. Hursthouse, Dalton Trans., 2006, 5717; (c) G. L. Moxham, H. E. Randell-Sly, S. K. Brayshaw, R. L. Woodward, A. S. Weller and M. C. Willis, Angew. Chem. Int. Ed., 2006, 45, 7618; (d) R. Malacea, J.-C. Daran, S. B. Duckett, J. P. 1 Dunne, C. Godard, E. Manoury, R. Poli and A. C. Whitwood, Dalton Trans., 2006, 3350; (e) J. R. Dilworth, C. A. Maresca von Beckh W. and S. I. Pascu, Dalton Trans., 2005, 2151.

5 (a) D. K. Dutta, J. D. Woollins, A. M. Z. Slawin, D. Konwar, M. Sharma, P. Bhattacharyya and S. M. Aucott, J. Orgaomet. Chem.,

15 2006, 691, 1229; (b) J. E. Aguado, S. Canales, M. C. Gimeno, P. G. Jones, A. Laguna and M. D. Villacampa, Dalton Trans., 2005, 3005; (c) S. E. Durran, M. R. J. Elsegood and M. B. Smith, New J. Chem., 2002, 26, 1402; (d) J. Laube, S. Jäger and C. Thöne, Eur. J. Inorg. Chem., 2001, 1983; (e) E. G. Hope, T. Kemmitt and W. Levason, J.

$20 \quad$ Chem. Soc., Perkin Trans., 1987, 487; (f) S. K. Harbron, S. J. Higgins, E. G. Hope, T. Kemmitt and W. Levason, Inorg. Chim. Acta, 1987, 130, 43; (g) G. Dyer and D. W. Meek, J. Am. Chem. Soc., 1967, 89, 3983.

6 (a) V. Cadierno, J. Díez, J. García-Álvarez and J. Gimeno, Dalton 25 Trans., 2010, 39, 941; (b) C. Kling, H. Ott, G. Schwab and D. Stalke, Organometallics, 2008, 27, 5038.

7 (a) G. Hua and J. D. Woollins, Angew. Chem. Int. Ed., 2009, 48, 1368; (b) G. Hua, Y. Li, A. M. Z. Slawin and J. D. Woollins, Angew. Chem. Int. Ed., 2008, 47, 2857; (c) P. Kilian, S. Parveen, A. M.

30 Fuller, A. M. Z. Slawin and J. D. Woollins, Dalton Trans., 2008, 1908.

8 (a) T. J. Cunningham, M. R. J. Elsegood, P. F. Kelly, M. B. Smith and P. M. Staniland, Eur. J. Inorg. Chem., 2008, 2326; (b) G. M. Brown, M. R. J. Elsegood, A. J. Lake, N. M. Sanchez-Ballester, M. B. Smith, 5 T. S. Varley and K. Blann, Eur. J. Inorg. Chem., 2007, 1405.

9 (a) J. Hopewell, P. Jankowski, C. L. McMullin, A. G. Orpen and P. G. Pringle, Chem. Commun., 2010, 46, 100; (b) J. H. Downing, J. Floure, K. Heslop, M. F. Haddow, J. Hopewell, M. Lusi, H. Phetmung, A. G. Orpen, P. G. Pringle, R. I. Pugh and D. Zambrano-Williams, Organometallics, 2008, 27, 3216.

10 P. Machnitzki, T. Nickel, O. Stelzer and C. Landgrafe, Eur. J. Inorg. Chem., 1998, 1029.

11 (a) L. Vigo, M. Risto, E. M. Jahr, T. Bajorek, R. Oilunkaniemi, R. S. Laitinen, M. Lahtinen and M. Ahlgrén, Cryst. Growth Des., 2006, 6,

45 2376; (b) N. R. Champness, W. Levason, J. R. Quirk, G. Reid and C. S. Frampton, Polyhedron, 1995, 14, 2753.

12 M. D. Milton, J. D. Singh and R. J. Butcher, Phosphorus, Sulfur and Silicon, 2001, 169, 153.

13 A. Bondi, J. Phys. Chem., 1964, 68, 441.

5014 (a) B. A. Trofimov, N. K. Gusarova, S. N. Arbuzova, N. I. Ivanova, A. V. Artem'ev, P. A. Volkov, I. A. Ushakov, S. F. Malysheva and V. A. Kuimov, J. Organomet. Chem., 2009, 694, 677; (b) N. K. Gusarova, N. A. Chernysheva, S. V. Yas'ko, T. I. Kazantseva, I. A. Ushakov and B. A. Trofimov, Synthesis, 2008, 2743.

5515 For a recent alternative synthesis of 4 see: A. M. Spokoyny, M. S. Rosen, P. A. Ulmann, C. Stern and C. A. Mirkin, Inorg. Chem., 2010, 49, 1577. 